\title{
PENGARUH KONVENSI PUISI SUPRAKATA TERHADAP MAKNA PUISI
}

\author{
Fathin Najla \\ Irfan Efendi \\ Dwi Wahyu Pria K \\ Universitas Muhammadiyah Malang \\ Fathinnajla@gmail.com
}

\begin{abstract}
Abstrak:
Penelitian ini bertujuan untuk mengungkapkan pengaruh bentuk puisi suprakata terhadap makna puisi yang diambil dari pengarang yang berbeda, untuk membuktikan bahwa setiap pengarang memiliki gaya kepenulisan yang berbeda terkait dengan bentuk dan gaya bahasa puisi suprakata. Penelitian ini menggunakan penelitian kualitatif dengan metode analisis isi. Penelitian ini dikaji dengan pendekatan stilistika yang mengkaji bentuk dan gaya bahasa puisi suprakata dari pengarang Sapardi Djoko Damono, Joko Pinurbo, dan Sides Sudyarta. Hasil penelitian menunjukkan bahwa konsep kepenulisan puisi suprakata berbeda anatara pengarang satu dengan pengarang yang lainnya, 1) Sapardi Djoko Damono menggunakan gaya dan bentuk bahasa yang cenderung imajinatif dan menggunakan pengulangan kata pada awal kalimat, Pengaruh bentuk puisi terhadap makna puisi adalah memberikan penekanan terhadap permasalahan dalam hidup yang berusaha disampaikan pengarang. Kata siapa dalam puisi sonnet $\mathrm{x}$ yang terus diulang memberikan penekanan bahwa manusia adalah objek yang melakukan dan nantinya yang akan mendapatkan akibat dari yang dilakukan 2) Joko Pinurbo menggunakan gaya dan bentuk bahasa yang nyata dan bersifat rasional serta pengulangan kata pada akhir kalimat, Pengaruh bentuk puisi terhadap makna dalam puisi berjudul Naik Bus karya Joko Pinurbo dimaknai sebagai kejamnya kehidupan yang ada di perkotaan demi sesuap nasi bahkan nyawa pun akan dipertaruhkan dengan uang. 3) Sides Sudyarta menggunakan gaya dan bentuk bahasa yang cenderung konseptual terhadap konsep puisi suprakata yaitu cenderung menjungkirbalikkan kata-kata konvensional sehingga memunculkan kosa kata baru yang belum pernah ada. Kata ya dalam puisinya adalah sebagai penekanan bahwa upacara ini dilakukan untuk orangorang yang masih percaya bahwa laut mamiliki bahaya dan perlu disucikan.
\end{abstract}

Kata kunci: puisi, suprakata, pengarang

\section{PENDAHULUAN}

Karya sastra merupakan bentukan daripada konflik atau gejala-gejala yang ada kemudian dikemas dengan karya tulis maka tercipta estetika dalam sebuah karya tulis tersebut (Ratna, 2013:206). Puisi bukan hanya sebagai media hiburan, tetapi puisi juga merupakan salah satu upaya dalam mengembangkan kebudayaan daerah untuk mengambil pesan-pesan moral sejarah yang tersirat dalam bentuk dan nilai budaya teks puisi. Maka puisi merupakan salah satu 
karya sastra yang amat memperhatikan aspek kebahasaan yang digunakan (Darwati, 2012:6). Dalam perkembangan teks puisi ini, bentuk dan penggunaan bahasa di dalam teksnya pun bermacam-macam. Teks puisi mempunyai nilai estetik tidak hanya dalam pemaknaannya akan tetapi bentuk dan Bahasa yang digunakannya pun mempengaruhi nilai estetik dalam teks puisi.

Bahasa merupakan aspek terpenting dalam penyampaian maksud pengarang di dalam penulisan puisi. Bahasa di dalam karya sastra bisa dikatakan sebagai seleksi daripada Bahasa tertentu, artinya kebahasaan dalam teks puisi mempunyai makna tersendiri tergantung pada aspek yang mempengaruhi atau akibat tekanan-tekanan yang ada. (Warren \& Wellek, 2016:198). Demikian pula dengan bentuk teks puisi. Di dalam perkembangannya, bentuk serta bahasa yang di gunakanan dalam karya sastra teks puisi juga mengalami beberapa gejala-gejala yang mempengaruhi. Bentuk puisi suprakata, mini kata, tanpa kata. Dalam bentuk dan gaya bahasa teks puisi tersebut mempunyai keunikan. Dengan gaya bahasa yang di ulang-ulang, bentuk teks yang tidak rata atau bentuk puisi yang hanya ada satu kalimat. Hal ini karya sastra teks puisi mempunyai pemaknaan tersendiri dalam hubungan setiap kalimatnya maupun hubungan kalimat dan bentuk dari pada teks puisi (Warren \& Wellek, 2016:200).

Puisi Suprakata merupakan salah satu jenis puisi kontemporer dalam kesusastraan Indonesia yang memiliki konsep penjungkirbalikan kata sehingga memunculkan kosa kata baru yang belum pernah ada sebelumnya yang bersifat konvensional dan lebih mengedepankan aspek bunyi daripada makna kata.

Penelitian ini penting untuk dilakukan untuk memberikan gambaran terhadap pembaca mengenai pengaruh bentuk puisi suprakata terhadap makna puisi. Objek penelitian ini antara lain menggunakan puisi milik Sapardi Djoko Damono yang berjudul Sonet:x, puisi milik Joko pinurbo yang berjudul Naik bus, dan puisi milik Sides Sudyarto yang berjudul Zaman Bahari. Penelitian ini akan membahas tentang bentuk puisi suprakata yang berpengaruh ke dalam makna puisi.

Permasalahan yang akan di teliti terkait pengaruh bentuk puisi suprakata ke dalam makna puisi. bentuk dan gaya bahasa dalam sebuah karya sastra teks puisi ini di pengaruhi oleh gejala-gejala yang ada pada pengarang saat mengekpresikan ide dan gagasanya melalui karya sastra teks puisi, sehingga mencipataka estetika dalam pemaknaan dan pemahaman pembaca yang 
berbeda dalam gaya Bahasa dan bentuknya tergantung pada fokus penelitian menurut perkembangannya (Suwignyo,2018:213).

Ada beberapa peneliti yang meneliti terkait kebahasaan dan juga bentuk puisi. (1) Fajar Setio Utomo dan Rosida Erowati. Dalam jurnalnya beliau meneliti terkait tentang pemaknaan Bahasa dalam puisi sufistik dengan berfokus pada tasawuf. Beliau menggunakan teori semiotika, yang mana membahas terkait simbol pada puisi yang di telitinya. (2) Darusman A. R. Peneliti ini meneliti puisi lama atau yang biasa di sebut dengan syair. Beliau berfokus pada syair melayu dengan pengkajian Bahasa sehingga menghasilkan estetika melalui irama atau bunyi setiap barisnya dalam karya teks puisi..

Dari beberapa peneliti di atas, tidak dipungkiri bahwa masih ada keterbatasan dalam penelitiannya. Artinya dalam perkembangan karya sastra teks puisi masih banyak permasalahan untuk di analisis dalam berbagai macam aspek sehingga menciptakan estetika tersendiri dalam pemaknaan yang berbeda oleh pembaca. Akan tetapi beberapa hasil peneliti di atas, sangat membantu peneliti untuk menganalisis bentuk dalam karya sastra teks puisi dengan menggunakan aspek yang berbeda. Hal ini mengingat bahwa karya sastra puisi bisa berubah sesuai dengan evolusi sehingga memunculkan inovasi dalam bentuk ataupun penggunaan bahasanya..

Pada kenyataannya, sejauh ini analisis di bidang sastra khususnya puisi masih sangat terbatas. Para peneliti sastra di bidang puisi, masih memiliki kesempatan untuk menganalisis bidang sastra terkait puisi. Sastra merupakan suatu komunikasi yang mengandung unsur seni dan unsur kreativitas, sastra yang selalu berada dalam ketegangang antar konvensi salah satunya karya sastra dan inovasi yang merupakan pembaharuan cara penulisan. Penulis mengejawantahkan dalam konteks bentukbentuk puisi yang selalu berubah-ubah akibat evolusi. Bahwasanya penelitian di bidang sastra masih sangat kurang, dan karya sastra sendiri terus lahir, berkembang, dan tidak pernah mati. Maka penulis masih mempunyai keleluasaan untuk melakukan penelitian yang belum benyak diteliti, yaitu bidang puisi suprakata, mini kata, tanpa kata dan Bahasa yang digunakannya. Berkenaan pernyataan di atas maka penelitian bentukbentuk puisi seperti suprakata, mini kata, tanpa kata penting untuk dilakukan.

Menindaklanjuti terhadap pernyataan di atas penelitian ini berfokus pada pengaruh bentuk puisi suprakata ke dalam makna 
puisi. Dengan penggunaan teori stilistika. Dalam tataran yang lebih luas yang berhubungan dengan keilmuan makna teori berarti perangkat pengertian, konsep, proposisi yang mempunyai korelasi dan telaah teruji kebenarannya (Nyoman, 2015:1). Stilistika secara definitif merupakan ilmu yang berkaitan dengan gaya bahasa. Dengan keterkaitan peneliti ingin meneliti bentuk dan bahasa yang di gunakan pada karya sastra puisi seperti suprakata, mini kata atau tanpa kata, maka teori stilistika relevan untuk menganalisis beberapa karya sastra yang berkaitan dengan gaya bahasa dan bentuk teks puisi.

\section{KAJIAN PUSTAKA}

Penelitian ini menggunakan teori Blake dan Christoper Smart yang menjelaskan tentang konsep bahasa puisi. Menurut Blake dan Christoper Smart menunjukkan bahwa orang yang dikuasai oleh pandangan irasional atau antirasional dapat mengubah diksi puitis atau mengembalikan diksi ke kebiasaan fase sebelumnya (Wellek \& Warren, 2016:199)

Bateson (dalam Wellek \& Warren, 2016:199) menyatakan bahwa puisi secara pasif mencerminkan perubahan linguistik. Pendapat bateson berbanding terbalik dengan pendapat Blake dan Christoper, Bateson lebih menekankan bahwa puisi dan bentuk bahasa tidak memiliki hubungan dengan linguistik. Sedangkan Blake dan Christoper sependapat dengan para peniliti terdahulu yang menyatakan dalam penelitiannya bahwa linguistik merupakan faktor yang sangat mempengaruhi bentuk dan gaya bahasa pada puisi.

Dalam buku yang ditulis oleh Lazare Sainean mengungkapkan bahwa karya sastra digunakan sebagai sumber dan dokumen untuk linguistik, tapi studi linguistik hanya bermanfaat untuk studi sastra jika bertujuan meneliti efek estetis bahasa.

Menurut Charless Bally (dalam Wellek \& Warren, 2016:203) stilistika hanya sebagai bagian dari linguistik, tetapi stilistika sebagai ilmu mandiri ataupun bukan tetap memiliki permasalahannya sendiri. Meliputi ujaran manusia dan juga wilayah yang lebih luas dari sastra ataupun retorika.

Stilistika mempunyai sarana yang lebih tepat dibandingkan studi-studi terdahulu tentang bentuk-bentuk berdasarkan klasifikasi retorika, dan spekulasi gaya periode yang lebih luas tapi kurang konkret. (Wellek \& Warren, 2016:205)

Dari beberapa pendapat para ahli dapat disimpulkan bahwa puisi memiliki makna yang sangat kontekstual. Kata-kata tidak hanya memiliki makna tertentu tetapi 
membangkitkan kesadaran pembaca bahwa kata-kata berkaitan dengan bunyi atau makna tersebut. Begitupun dengan teori stilistika bisa diterapkan dengan baik hanya apabila kita memahami linguistik dengan benar. Karena stilistika dan linguistik sangat berkaitan. Dalam analisis karya sastra unsur fonetik bahasa tidak dapat dipisahkan dari makna. Begitupun sebaliknya bahwa struktur makna juga cocok untuk untuk menganalisis linguistik.

\section{METODE PENELITIAN}

Dalam meneliti bentuk dan gaya bahasa dari puisi suprakata ini menggunakan metode kualitatif. Metode kualitatif memberikan perhatian terhadap data alamiah, data dalam hubungannya dengan konteks keberadaannya.

Landasan berpikir metode kualitatif adalah pradigma positivisme Max Weber, Immanuel Kant, dan Wilhelm Dilthey (Moleong, 1989:10-11). Metode kualitatif dianggap persis sama dengan metode pemahaman. Metode kualitatif merupakan metode penelitian yang mempertahankan nilai-nilai. Dalam ilmu sosial sumber datanya adalah masyrakat, data penelitiannya adalah tindakan-tindakan. Sedangkan dalam ilmu sastra sumber datanya adalah karya, naskah, data penelitiannya, sebagai data formal adalah kata-kata, kalimat, wacana (Ratna, 2015: 47)

Sumber data dalam penelitian ini berupa kumpulan puisi suprakata dari beberapa pengarang yang berbeda yakni puisi dari Sapardi Djoko Damono, Joko Pinurbo, dan Sides Sudyarto DS. Hal yang akan diteliti adalah bentuk dan gaya bahasa dari puisi suprakata.

Teknik pengumpulan data dalam penelitian ini menggunakan studi dokumen. Studi dokumen meneliti beberapa macam data yang digunakan sebagai bahan analisis. Langkah-langkah studi dokumen meliputi 1) Membaca kumpulan puisi suprakata dari pengarang yang berbeda-beda, 2) Menganalisis perbedaan bentuk dan gaya bahasa dari pengarang yang menulis puisi suprakata, 3) menggambarkan secara umum perbedaan model penulisan puisi suprakata dari beberapa pengarang yang berbeda.

Teknik analisis yang digunakan dalam penelitian bentuk dan gaya bahasa dari puisi suprakata ini adalah teknik analisis isi. Teknik analisis isi tidak hanya mampu menemukan perbedaan letak gaya bahasa pada puisi suprakata tetapi juga dapat membantu menemukan makna yang terkandung dalam puisi suprakata dari beberapa pengarang yang berbeda. 
Untuk mengecek keabsahan data peneliti melakukan triangulasi. Ketiga triangulasi tersebut antara lain 1) triangulasi teori, 2) triangulasi sumber data, 3) triangulasi peneliti. Melalui uji validitas tersebut membantu peneliti dalam menemukan teori yang cocok digunakan sebagai bahan acuan penelitian.

\section{PEMBAHASAN}

Kumpulan puisi suprakata dari Sapardi Djoko Damono, Joko Pinurbo, dan Sides Sudyarto DS memiliki model bentuk dan gaya bahasa yang berbeda dalam menulis puisi suprakata sehingga menimbulkan pengaruh terhadap makna puisi.

Pengaruh bentuk puisi suprakata terhadap makna puisi suprakata oleh Sapardi Djoko Damono, Joko Pinurbo, dan Mustofa Bisri.

\section{a. Puisi Suprakata Sapardi Djoko Damono}

Dalam puisi suprakata yang ditulis Sapardi yang berjudul Sonet:x, menggunakan gaya bahasa yang cenderung menggunakan diksi berulang yang sama pada setiap awal kalimat. Jika dikaitkan dengan teori Blake dan Christoper Smart, Sapardi cenderung dikuasai oleh pandangan irasional yang terlihat dari pemilihan diksi yang lebih cenderung imajinatif dan puitis, sehingga mengembalikan diksi ke kebiasaan fase sebelumnya.

Siapa menggores di langit biru siapa meretas di awan lalu siapa mengkristal dikabut itu siapa mengertap di bunga layu siapa cerna di warna ungu siapa bernafas di detak waktu (1968) Dalam penggalan puisi berjudul Sonet:x tersebut menggambarkan makna tentang kehidupan. Penulis berusaha menyampaikan tentang permasalahan dalam hidup yang memiliki sebab akibat. pemilihan gaya bahasa yang puitis dan imajinatif serta bentuk bahasa yang menggunakan pengulangan pada kata awal yang berbunyi siapa. Dalam konsep puisi suprakata memiliki konsep kata konvensional yang dijungkirbalikkan, tetapi Sapardi tidak menjungkirbalikkan kata, Sapardi memberi penekanan pada kata siapa yang ditulis secara berulang-ulang. Puisi ini juga termasuk puisi suprakata karena lebih memperhatikan aspek bunyi daripada makna kata. Pengaruh bentuk puisi terhadap makna puisi adalah memberikan penekanan terhadap permasalahan-permasalahan dalam hidup yang berusaha disampaikan pengarang. Kata siapa dalam puisi sonnet $\mathrm{x}$ yang terus diulang memberikan penekanan bahwa manusia adalah objek yang 
melakukan dan kelak nantinya yang akan mendapatkan dampak dari apa yang dilakukan. Terbukti dari kumpulan puisi yang di tulis secara berurutan dengan tema dan makna yang berkaitan satu sama lain. Karya puisi Sapardi dengan judul sonet seperti mempunyai keterkaitan karena Sapardi menciptakan puisi berjudul sonet beberapa kali sampai akhirnya Sapardi menciptakan puisi berjudul Sonet $\mathrm{x}$ untuk menegaskan puisi-puisi sebelumnya.

\section{b. Puisi Suprakata Joko Pinurbo}

Dalam puisi suprakata yang ditulis oleh Joko Pinurbo yang berjudul Naik Bus di Jakarta, menggunakan gaya bahasa yang sama dengan model penulisan dari Sapardi yakni dengan diksi yang berulang. Jika dilihat dari diksi yang dipilih oleh Joko Pinurbo maka Joko Pinurbo cenderung dikuasai oleh pemikiran rasional, karena Joko Pinurbo menggunakan diksi yang lebih bersifat nyata dan tidak imajinatif.

\section{Sopirnya sepuluh}

Kernetnya sepuluh

Kondekturnya sepuluh

Pengawalnya sepuluh

Perampoknya sepuluh

Dalam penggalan puisi Joko Pinurbo yang berjudul Naik Bus di Jakarta tersebut menggambarkan gaya bahasa yang bersifat rasional dan nyata. Puisi Suprakata Joko Pinurbo ini memang tidak menjungkirbalikkan kata tetapi cenderung memperhatikan aspek bunyi daripada makna sehingga puisi ini juga termasuk ke dalam puisi suprakata. Pengaruh bentuk puisi terhadap makna dalam puisi berjudul Naik Bus karya Joko Pinurbo dimaknai sebagai kejamnya hiruk pikuk yang ada di perkotaan yang sangat kejam karena demi sesuap nasi bahkan nyawa pun akan dipertaruhkan dengan pundi-pundi uang. Penegasan kata sepuluh yang terus diulang yang menegaskan bahwa kehidupan di perkotaan sangat padat dan juga semua kaum berlomba-lomba untuk memperoleh keuntungan yaitu uang demi sesuap nasi.

\section{c. Puisi Suprakata Sides Sudyarto DS}

Puisi yang ditulis oleh Sides Sudyarto DS yang berjudul Puisi Zaman Bahari menggunakan gaya bahasa yang sangat konseptual dengan konsep puisi suprakata, yaitu menjungkirbalikkan kata-kata konvensional sehingga muncul kosa kata baru yang belum pernah ada sebelumnya. Cenderung dikuasai oleh pemikiran irasional dan sangat mementingkan aspek bunyi.

\section{Ya meraja jaramaya}

Ya marani niramaya 


\section{Ya sialapa palasia}

\section{Ya milado rodamiya}

Dalam penggalan puisi Sides Sudyarto DS yang berjudul Puisi Zaman Bahari tersebut menggambarkan gaya bahasa yang abstrak dan sulit untuk dipahami apa maksud dari penulisan puisi tersebut. Karena menggunakan kata yang dijungkirbalikkan dan hampir sama. Puisi Suprakata jenis ini adalah puisi suprakata yang paling selaras dengan konsep puisi suprakata. Pengaruh bentuk puisi suprakata terhadap makna puisi adalah memberikan pesan kepada orang yang melakukan upacara adat untuk menjauhkan bala dari laut. Kata ya dalam puisinya adalah sebagai penekanan bahwa upacara ini dilakukan untuk orang-orang yang masih percaya bahwa laut mamiliki mara bahaya dan perlu diselamati. Dilihat dari judulnya juga menunjukkan bahwa bahari atau laut merupakan tempat yang perlu dihargai lebih dairi tempat lain dikarenakan membawa kehidupan bagi orang banyak.

Jika dikaitkan dengan teori christopers smart maka puisi suprakata zaman bahari ini cenderung menggunakan pandangan antirasioanl dikarenakan masih mempercayai mistis-mistis dalam sebuah budaya sehingga mampu menimbulkan pengulangan diksi.

Dari penggalan-penggalan puisi suprakata dari beberapa pengarang yang berbeda memberikan pengetahuan bahwa puisi suprakata bukan hanya puisi yang kata konvensionalnya dijungkir balikkan sehingga cenderung menimbulkan kosa kata yang aneh dan sulit dipahami, tetapi puisipuisi yang cenderung mementingkan aspek bunyi daripada makna adalah juga termasuk kedalam puisi suprakata. Karena salah satu tanda puisi suprakata adalah lebih mengedepankan aspek bunyi daripada makna. Dan setiap pengarang memiliki konsep yang berbeda terhadap penulisan puisi suprakata. Bentuk puisi suprakata juga memiliki pengaruh kepada makna setia puisi, terlepas dari irama bunyi yang lebih dipentingkan, bentuk puisi suprakata memberikan makna yang lebih dalam daripada puisi yang konvensi nya umum.

\section{KESIMPULAN}

Berdasarkan paparan pembahasan dapat disimpulkan bahwa puisi suprakata merupakan salah satu jenis puisi kontemporer yang ada dalam kesusastraan Indonesia. Puisi suprakata memiliki konsep kata konvensional yang diulang dan dijungkirbalikkan sehingga memunculkan kosa kata baru yang belum pernah ada sebelumnya dan lebih mengedepankan aspek bunyi dari pada makna kata. Dan setiap pengarang memiliki gaya kepenulisan yang 
berbeda dalam menulis puisi suprakata yang mencakup gaya dan bentuk bahasa. 1) Sapardi Djoko Damono menggunakan gaya dan bentuk bahasa yang cenderung imajinatif dan menggunakan pengulangan kata pada awal kalimat, dan pengaruh bentuk puisi suprakata terhadap makna puisi dari Sapardi adalah adalah memberikan penekanan terhadap permasalahan-permasalahan dalam hidup yang berusaha disampaikan pengarang. Kata siapa dalam puisi sonnet $\mathrm{x}$ yang terus diulang memberikan penekanan bahwa manusia adalah objek yang melakukan dan kelak nantinya yang akan mendapatkan dampak dari apa yang dilakukan. 2) Joko Pinurbo menggunakan gaya dan bentuk bahasa yang cenderung nyata dan bersifat rasional serta pengulangan kata pada akhir kalimat. Pengaruh bentuk puisi suprakata pada puisi dari Joko Pinurbo adalah Penegasan kata sepuluh yang terus diulang yang menegaskan bahwa kehidupan di perkotaan sangat padat dan juga semua kaum berlomba-lomba untuk memperoleh keuntungan yaitu uang demi sesuap nasi. 3) Sides Sudyarta DS menggunakan gaya dan bentuk bahasa yang cenderung konseptual terhadap konsep puisi suprakata yaitu cenderung menjungkirbalikkan kata-kata konvensional sehingga memunculkan kosa kata baru yang belum pernah ada sebelumnya. Pengaruh bentuk puisi suprakata pada puisi Sides adalah Kata ya dalam puisinya adalah sebagai penekanan bahwa upacara ini dilakukan untuk orangorang yang masih percaya bahwa laut mamiliki mara bahaya dan perlu diselamati. Dilihat dari judulnya juga menunjukkan bahwa bahari atau laut merupakan tempat yang perlu dihargai lebih dairi tempat lain dikarenakan membawa kehidupan bagi orang banyak. 